\title{
Investigation of Support Service Acquirement and Demand for Special Student Families
}

\author{
$\mathrm{Xiu} \mathrm{Li}^{*}$ \\ College of the Special Education \\ Leshan Normal University \\ Leshan, China
}

\begin{abstract}
In order to unveil the status quo and demand of special student families accessible to family support service and analyze the differences between the acquirement and demand for the family support service by different families and children, the article conducts a questionnaire survey on parents of students studying in some special education schools in Sichuan province. The survey results show, (1) the status quo of special student families accessible to family support service is not as good as expected, of which, the spiritual and financial supports are better, yet the career planning and information supports are the least, and the acquirement of six family support services are obviously lower than the demand; (2) special student families are in a high demand for the six family support services, of which, the career planning ranks the first, followed by the information support; (3) the acquirement and demand for special student family support service vary obviously with parental education and occupation, children's grade, handicap classification and degree and more.
\end{abstract}

\section{Keywords—special students; family support; family demand}

\section{INTRODUCTION}

With the time going, the service of special education has been expanded from special students to the students-related families, and the view of ecological departmentalism is stressed to evaluate children's physical and mental development and unique demands and value the interactive relations between children, families and schools ( $\mathrm{Xu}$ Jianan, 2002). In the opinions of Karp and Bradley (1991) the development of family support service should be based on children whether they are disabled or not, all of whom are in the need of continuous care of families and relatives so as to exert the maximum potentials of their own. Due to the differences in handicap classification and degree as well possible other diseases, extremely great differences exist among students with handicaps, and the particularities of students will consequently bring a series of pressure to and demands of families. So in order to enable the families to take care of special children with better conditions, it can be considered the first task to meet the demands of the families. [1]

Family support refers to an aid in any form such as service, resources and the like, enabling individuals of any age who are disabled and families to live together and be members of the community (Freedman\& Boyer, 2000). The family support

* Li Xiu, female, master in special education, instructor, researches on teacher training in special education service offered may lower the physical and mental pressure of members of families with handicapped children and troubles in living adaptation (Li Qingsong, 1992), with the support acquired, the parents will have their willingness enhanced to participate in the student's learning.

Most recently, scholars at home and abroad have improved and deepened researches on various aspects (pressure to parents, family education, parental education, quality of family living, family demand, etc.) of families with the disabled, of the researches on families with the disabled, the family demand is a research field which have attracted more eyeballs in recent years in the country (Huang Xinyin et al [2], 2010; Gu Changfen, et al [3][4], 2010, 2012; Cai Zhuoni, et al [5], 2010; Hu Xiaoyi [6], 2016). Main researches concerned include survey on analysis of social support to special children families written by Cai Zhuoni, et al[5] (2010); survey of social support to special children families written by Huang Jingjing, et al [7] (2006); research on family demands and social support to autism children families written by Xiong Yingqi, et al[8 (2015). According to researches available, two characteristics are found, first, the research objects are mainly focused on students with dysgnosia and autism, but little involved in special students with other handicaps, even special children are involved in to some degree, there are no analysis of differences on the basis of the handicap classification; Second, most researches aim at survey and analysis of family demand and acquirement of families from social support, yet the acquirement of social support is separated from the family demand and no gap analysis is conducted on the acquirement and demand intensity. This article takes the families of students with different handicaps as an object for research, and investigates the acquirement and demand intensity of the family support service, making difference analysis of variables such as handicap classification, degree, parent's occupation and education as well as gap analysis of the acquirement of family support service and demand intensity, so as to provide references for educational agencies and schools when offering family services.

\section{RESEARCH DESIGN}

\section{A. Research Object}

Parents of students in special education schools are taken as objects for the research, whose children studying in grades 
1-9 at special education schools in Chengdu, Leshan, Nanchong, Guangyuan, Shuangliu and Guang'an in Sichuan province, and the students are involved in diverse classifications such as dysgnosia, hearing disorder, vision disorder, autism and so on. A total of 450 questionnaires are delivered, 385 of which are returned, and the returning rate reaches $85.6 \%, 328$ of which valid.

\section{B. Research Instruments}

Questionnaire survey is adopted for the research, which is abstracted from Questionnaire of Status Quo and Demands of Family Support Service to Special Student Family[1], written by Sun Shurong from National Hsinchu University of Education, and samples are selected for localized reliability analysis, the validity is based on the content, 3 special education experts, 5 special education teachers and 4 students' parents are invited to provide suggestions and correction according to the contents, structure, mood, diction and so on, based on which, the research makes a final modification and confirmation. Second, the reliability mainly relies on internal consistency tests, the results show both dimensions and internal consistency of the questionnaire have reached 0.8 or more, owning sound reliability. The questionnaire contains 45 topics and 6 dimensions (refer to "Table I"), and a four-point scale is adopted to score for the acquirement of family support service and demand intensity, and scores 4,3,2,1 is used to express many more, more, a few, no respectively; and scores 4,3,2,1 is also used to express extremely need, need, not need, completely not need respectively, the higher the score is, the acquirement of the service will be better and the higher the demand intensity for the service will be.

TABLE I. RELIABILITY OF DIMENSIONS FOR FAMILY SUPPORT SERVICE

\begin{tabular}{llll}
\hline \multirow{2}{*}{$\begin{array}{c}\text { Dimensions for family } \\
\text { support service }\end{array}$} & \multicolumn{2}{c}{ Coefficient of Internal Consistency } \\
\cline { 2 - 4 } & $\begin{array}{c}\text { Number of } \\
\text { Topics }\end{array}$ & Acquirement & $\begin{array}{c}\text { Demand } \\
\text { Intensity } \\
\text { in Service }\end{array}$ \\
\cline { 2 - 4 } 1. Spiritual support & 6 & .883 & .898 \\
2. Financial support & 5 & .869 & .898 \\
3. Information support & 10 & .942 & .915 \\
4. Professional service & 8 & .922 & .925 \\
support & 8 & .924 & .904 \\
5. Parental education course & 8 & .923 & .926 \\
6. Career planning & 8 & .933 & .917 \\
\hline Total reliability & 45 & & \\
\hline
\end{tabular}

\section{Results Process}

Spss 19.0 software is used for statistic analysis on the data of the results.

\section{RESEARCH RESULTS}

\section{A. Details of Participants}

Most participants are students' mothers (60.7\%); the degrees of students' parents are basically senior middle school or below $(63.4 \%)$; seen from jobs, most engage in low-level work (including workers, farmers and full time job, occupying $77.1 \%$ ); $93.2 \%$ of the parents are married and living with children with handicaps. Most special students are boys $(62.8 \%)$; most students have dysgnosia (48.2\%), followed by the deaf $(26.5 \%)$ and the last is autism $(14.3 \%)$; most of the handicaps are at a medium level (39.9\%), followed by extremely serious $(34.8 \%)$; most of the students study in a lower grade $(41.2 \%)$.

\section{B. Analysis of Acquirement and Demand Intensity of Family Support Service}

First, the researcher calculates the average value of acquirement and demand intensity of each topic shown through six dimensions concerning the support service, standard deviation and sorting, then take the matched samples $\mathrm{T}$ testing to get the difference between the acquirement and demand for support service by special student families through comparison (Refer to Table 2).

1) Acquirement and demand intensity of spiritual support: Survey results show, on the dimension of spiritual support, the parents get more support in "teachers give encouragement and emotional support" and "provide special education publicity, encourage all teachers and students to accept and take care of special children", yet they get extremely low scores in "acquire skills to relieve physical and mental pressure" and "professionals give ear to and know my thoughts or feelings", besides, the overall average score in acquirements of spiritual support is only 2.61 , from which, it can be found that the parents generally feel it inadequate to access to the service of spiritual support. On the demand, the average score is 3.423.60, of which, the demands for "teachers give encouragement and emotional support" and "provide special education publicity, encourage all teachers and students to accept and take care of special children" are the highest. The overall value of the demand is higher, reaching 3.50, which prove that the parents have higher demands for the spiritual support which is provided in any form.

2) Acquirements and demand intensity of financial support: On the acquirement of financial support, the overall average score is 2.35 , the "provide tuition and other fees exemption" gets the highest score, followed by "offer subsidy for textbooks"; yet the "offer subsidy for traffic costs or traffic service" gets the lowest score. On the demand intensity, the "provide tuition and other fees exemption" also gets the highest score, and the "offer subsidy for traffic costs or traffic service" gets the lowest score. On the sorting of acquirements and demand intensity of financial support, though most special student families can enjoy the financial support from authorities and education agencies, yet they still need tuition and other fees exemption, subsidy for textbooks, especially the subsidy to special equipment costs.

3) Acquirements and demand intensity of information support: On acquirements of information support, the average score is 2.19 , of which, the "offer information related to children's identification, arrangement and schooling" gets the highest score, followed by "offer information of personalized education plans, including students' development and teaching goals"; the "provide ways for appealing for students' rights protection" (1.95 points) and the "offer information of social resources and welfare agencies to help children currently or in the future" (2.04 points) get the lowest score each. On the demand intensity, the average score is 3.52 , besides, each topic 
is designed with a score of 3.42 or more, which prove that parents are in a great need of information support, especially the three aspects are in the highest demand, including "offer information of social resources and welfare agencies to help children currently or in the future", "offer information related to children's medical rehabilitation and healthcare" and "offer information concerning legal rights and social welfare that the parents and their children should enjoy", whose acquirements are in a obvious lack. The results show that the special students' parents have a higher demand for information concerning social resources or welfare agencies that may facilitate children currently or in the future, and for rules of application for social welfare concerned.

4) Acquirement and demand intensity of special service support: On acquirements of professional support service, the average score is 2.30 , of which, the "teachers provide assistances and help children for self care" gets the highest score, followed by "demonstrate simple treatment methods and help children for single follow-up exercise at home", yet the "psychological consultants offer constancy service to family members or groups" gets the lowest score, which prove that most of special students' parents think that teachers offer more assistance to children for self care in schools. On demands, the average score is 3.42 , indicating that the demands of students' parents for professional service are extremely higher, especially in a strong need of various treatments on special students. The results show, the prior demands of students' parents for professional team service belong to direct service, followed by "offer evaluation on children's medical care and assistance and raise suggestions", which is referred to as indirect service.

5) Acquirement and demand intensity of parental education course: On acquirements of parental education course, the average score is 2.26 , of which, the "offer methods to educate children and improve knowledge and skills for education" gets the highest score, followed by the "offer tricks to treat children's behavioral problems", yet the "hold parental interaction camp or outdoor teaching activities" and the "hold parental discussions" and the "offer methods to communicate with professionals" all bet lower scores, less than 2.20 points averagely. The average score of each topic is below 2.50, showing that the special student families have acquired few services in parental education courses. On demands, the average score is 3.43, showing the parents have higher demands for it, especially the "offer methods to educate children and improve knowledge and skills for education", the "offer tricks to treat children's behavioral problems" and the "offer methods to communicate with professionals" are in a highest demand. Seen from the sorting of acquirements and demand intensity, though the acquirements of training children in knowledge and ability and tricks to treat behavioral problems ranks first and second respectively, yet the sorting of the demand of the two is also in the first two, showing that the parents still need more tricks and knowledge to treat children's behavioral problems.

6) Acquirement and demand intensity of career planning: Seen from acquirements, the overall average score is 2.16 , of which, the "train children in self-care and social adaptation" gets the highest score, followed by the "carry out courses linking primary school and middle school, and help children continue learning", yet the "know which units could offer vocational training" gets the lowest score, namely 1.86 points only. Yet analyzed from the average value of the dimension, only the score of the first topic exceeds 2.5 points, the average value of all others are lower, showing that the parents get inadequate support service in the dimension of career planning. On demands, the overall average score is 3.57 , showing the special student families have higher demands in the dimension of career planning, of which, the "offer courses related to occupations and make children easy to find jobs after graduation" is in a highest demand, followed by "train children in self-care and social adaptation", and the last is "know which units could offer vocational training". Seen again from sorting, the demand for "know which units could offer vocational training" ranks 3, yet its sorting in acquirement is the least, from which we can see that an imbalance exists between supply and supply.

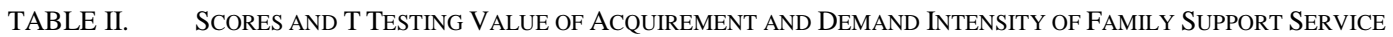

\begin{tabular}{|c|c|c|c|c|c|c|c|}
\hline \multirow[b]{2}{*}{ Item } & \multicolumn{3}{|c|}{ Acquirement } & \multicolumn{3}{|c|}{ Demand intensity } & \multirow[b]{2}{*}{ Value $\mathbf{t}$} \\
\hline & $\begin{array}{c}\text { Sortin } \\
\mathrm{g}\end{array}$ & $\begin{array}{c}\text { Average } \\
\text { Value }\end{array}$ & $\begin{array}{c}\text { Standard } \\
\text { Difference }\end{array}$ & Sorting & $\begin{array}{c}\text { Average } \\
\text { Value }\end{array}$ & $\begin{array}{c}\text { Standard } \\
\text { Difference }\end{array}$ & \\
\hline \multicolumn{8}{|l|}{ I. Spiritual support } \\
\hline 1. Teachers give encouragement and emotional support & 1 & 2.98 & .886 & 2 & 3.57 & .565 & $-11.446^{*}$ \\
\hline $\begin{array}{l}\text { 2. Professionals give ear to and know my thoughts or } \\
\text { feelings }\end{array}$ & 5 & 2.39 & 1.457 & 6 & 3.42 & 606 & $-12.644 *$ \\
\hline 3. School leaders value and support family demands & 3 & 2.70 & .880 & 3 & 3.49 & .580 & $-16.148^{*}$ \\
\hline $\begin{array}{l}\text { 4. Provide special education publicity, encourage all } \\
\text { teachers and students to accept and take care of special } \\
\text { children }\end{array}$ & 2 & 2.88 & .908 & 1 & 3.60 & .527 & $-13.742 *$ \\
\hline 5. Offer methods for emotional control & 4 & 2.42 & .935 & 5 & 3.44 & 613 & $-19.006^{*}$ \\
\hline $\begin{array}{l}\text { 6. Obtain tricks and methods to relieve physical and } \\
\text { mental pressure }\end{array}$ & 6 & 2.28 & .981 & 4 & 3.45 & .603 & $-20.679^{*}$ \\
\hline Overall & & 2.62 & .791 & & 3.50 & .453 & $-20.746^{*}$ \\
\hline \multicolumn{8}{|l|}{ II. Financial support } \\
\hline 7. Provide tuition and other fees exemption & 1 & 2.97 & .933 & 1 & 3.47 & 685 & $-9.271 *$ \\
\hline 8. Offer application for student subsidies & 3 & 2.19 & 1.024 & 4 & 3.33 & .766 & $-18.806^{*}$ \\
\hline 10. Offer subsidies to special equipment costs & 4 & 2.13 & 1.074 & 2 & 3.37 & .705 & $-20.083^{*}$ \\
\hline 11. Offer subsidies to traffic costs or traffic service & 5 & 1.96 & 1.063 & 5 & 3.26 & .793 & $-19.597 *$ \\
\hline Overall & & 2.35 & .826 & & 3.37 & 620 & $-20.830 *$ \\
\hline
\end{tabular}




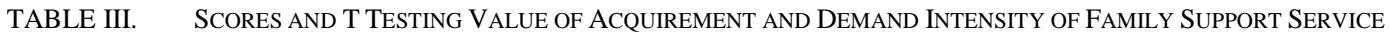

\begin{tabular}{|c|c|c|c|c|c|c|c|}
\hline \multirow[b]{2}{*}{ Item } & \multicolumn{3}{|c|}{ Acquirement } & \multicolumn{3}{|c|}{ Demand intensity } & \multirow[b]{2}{*}{ Value t } \\
\hline & Sorting & $\begin{array}{c}\text { Average } \\
\text { Value }\end{array}$ & $\begin{array}{c}\text { Standard } \\
\text { Difference }\end{array}$ & Sorting & $\begin{array}{l}\text { Average } \\
\text { Value }\end{array}$ & $\begin{array}{c}\text { Standard } \\
\text { Difference }\end{array}$ & \\
\hline \multicolumn{8}{|l|}{ III. Information support } \\
\hline $\begin{array}{l}\text { 12. Offer information of personalized education plans, } \\
\text { including students' development and teaching goals }\end{array}$ & 2 & 2.35 & .922 & 7 & 3.49 & .564 & $-21.036^{*}$ \\
\hline $\begin{array}{l}\text { 13. Offer information related to children's identification, } \\
\text { arrangement and schooling }\end{array}$ & 1 & 2.38 & .887 & 4 & 3.53 & .574 & $-21.688 *$ \\
\hline $\begin{array}{l}\text { 14. Offer information related to children's medical } \\
\text { rehabilitation and healthcare }\end{array}$ & 4 & 2.25 & .920 & 2 & 3.56 & .577 & $-23.349 *$ \\
\hline $\begin{array}{l}\text { 15. Offer information of social resources and welfare } \\
\text { agencies to help children currently or in the future }\end{array}$ & 8 & 2.04 & .947 & 1 & 3.65 & .537 & $-27.064 *$ \\
\hline 16. Fully promote ways for consultancy service & 5 & 2.14 & .894 & 9 & 3.45 & .588 & $-24.986 *$ \\
\hline $\begin{array}{l}\text { 17. Fully promote project of family support service offered } \\
\text { by authorities or relevant agencies }\end{array}$ & 7 & 2.11 & .903 & 5 & 3.52 & .580 & $-25.146^{*}$ \\
\hline $\begin{array}{l}\text { 18. Offer information of children's arrangement in summer } \\
\text { or winter holidays }\end{array}$ & 3 & 2.28 & .942 & 10 & 3.42 & .620 & $-21.262 *$ \\
\hline $\begin{array}{l}\text { 19. Offer information concerning legal rights and social } \\
\text { welfare that children should enjoy }\end{array}$ & 5 & 2.14 & .885 & 3 & 3.54 & .523 & $-25.989 *$ \\
\hline $\begin{array}{l}\text { 20. Offer information concerning application for welfare } \\
\text { and relevant requirements }\end{array}$ & 6 & 2.13 & .868 & 6 & 3.50 & .553 & $-26.001 *$ \\
\hline $\begin{array}{l}\text { 21. Provide ways for appealing for students' rights } \\
\text { protection }\end{array}$ & 9 & 1.95 & .936 & 8 & 3.45 & .604 & $-26.110^{*}$ \\
\hline ( & & 2.19 & .771 & & 3.52 & .443 & $-29.321 *$ \\
\hline \multicolumn{8}{|l|}{ IV. Professional service support } \\
\hline $\begin{array}{l}\text { 22.Schools or assisting agencies provide professional } \\
\text { special education consultancy and service }\end{array}$ & 3 & 2.27 & .876 & 7 & 3.09 & .867 & $-14.983 *$ \\
\hline $\begin{array}{l}\text { 23. Professional teams conduct evaluation on the } \\
\text { education, medical care and assistance needed by children } \\
\text { and raise specific suggestions }\end{array}$ & 5 & 2.16 & .953 & 8 & 3.05 & .930 & $-14.447 *$ \\
\hline 24.Offer children with physical therapy & 7 & 1.95 & .913 & 4 & 3.44 & .668 & $-27.412 *$ \\
\hline 25. Offer children with occupational therapy & 6 & 1.99 & .942 & 3 & 3.46 & .620 & $-25.337 *$ \\
\hline 26.Offer children with language therapy & 4 & 2.24 & .887 & 1 & 3.56 & .544 & $-25.327 *$ \\
\hline $\begin{array}{l}\text { 27.Psychologists offer consultancy service to individuals of } \\
\text { family members or teams }\end{array}$ & 8 & 1.86 & .937 & 6 & 3.37 & .708 & $-26.089 *$ \\
\hline $\begin{array}{l}\text { 28. Offer teaching assistant (as living aunt) to help children } \\
\text { for self care at school }\end{array}$ & 1 & 2.89 & .945 & 5 & 3.45 & .680 & $-11.762 *$ \\
\hline $\begin{array}{l}\text { 29. Demonstrate simple treatment methods and help } \\
\text { children for single follow-up exercise at home }\end{array}$ & 2 & 2.76 & .955 & 2 & 3.49 & .616 & $-12.850^{*}$ \\
\hline Overall & & 2.30 & .758 & & 3.42 & .554 & $-26.053 *$ \\
\hline \multicolumn{8}{|l|}{ V. Parental education courses } \\
\hline $\begin{array}{l}\text { 30. Offer methods to educate children and improve } \\
\text { knowledge and skills }\end{array}$ & 1 & 2.42 & .872 & 1 & 3.52 & .564 & $-20.888^{*}$ \\
\hline 31.Offer tricks to treat children's behavioral problems & 2 & 2.39 & .843 & 2 & 3.50 & .542 & $-22.334 *$ \\
\hline 32. Offer books and textbooks related to parental education & 5 & 2.20 & .885 & 4 & 3.43 & .622 & $-23.960 *$ \\
\hline 33. Hold parental discussions & 7 & 2.12 & .900 & 7 & 3.34 & .640 & $-22.695 *$ \\
\hline $\begin{array}{l}\text { 34. Hold parental interaction camp or outdoor teaching } \\
\text { activities }\end{array}$ & 8 & 2.10 & .907 & 6 & 3.37 & .628 & $-24.072 *$ \\
\hline $\begin{array}{l}\text { 35. Hold parental sport games or children's achievements } \\
\text { show }\end{array}$ & 4 & 2.31 & .858 & 5 & 3.39 & .558 & $-22.118^{*}$ \\
\hline $\begin{array}{l}\text { 36. Offer methods to create favorable family atmosphere } \\
\text { and circumstances }\end{array}$ & 3 & 2.37 & .907 & 5 & 3.39 & .631 & $-18.362 *$ \\
\hline 37. Offer methods to communicate with professionals & 6 & 2.17 & .920 & 3 & 3.47 & .574 & $-25.606 *$ \\
\hline Overall & & 2.26 & .760 & & 3.43 & .528 & $-27.440^{*}$ \\
\hline \multicolumn{8}{|l|}{ VI. Career planning } \\
\hline 38. Train children in self-care and social adaptation & 1 & 2.53 & .861 & 2 & 3.64 & .506 & $-22.221 *$ \\
\hline $\begin{array}{l}\text { 39. Carry out courses linking primary school and middle } \\
\text { school, and help children continue learning }\end{array}$ & 2 & 2.40 & .941 & 7 & 3.53 & .563 & $-21.321 *$ \\
\hline $\begin{array}{l}\text { 40. Hold meetings of children education and occupation } \\
\text { linking and provide relevant service }\end{array}$ & 5 & 2.08 & .959 & 7 & 3.53 & .541 & $-25.734^{*}$ \\
\hline 41. Provide ways for children's further studies & 3 & 2.15 & .916 & 6 & 3.57 & .576 & $-24.431 *$ \\
\hline $\begin{array}{l}\text { 42. Offer courses related to occupations and make children } \\
\text { easy to find jobs after graduation }\end{array}$ & 4 & 2.11 & .967 & 1 & 3.67 & .503 & $-26.834^{*}$ \\
\hline 43. Know which units could offer vocational training & 8 & 1.86 & .915 & 3 & 3.60 & .549 & $-30.329 *$ \\
\hline $\begin{array}{l}\text { 44. School continues tracking and assistance after } \\
\text { children's gradation }\end{array}$ & 6 & 2.03 & .931 & 5 & 3.58 & .553 & $-27.417 *$ \\
\hline $\begin{array}{l}\text { 45. Provide proper careen planning and suggestions for } \\
\text { children }\end{array}$ & 7 & 2.01 & .948 & 4 & 3.59 & .579 & $-27.106^{*}$ \\
\hline Overall & & 2.16 & .820 & & 3.57 & .484 & $-29.807 *$ \\
\hline
\end{tabular}




\section{Analysis of Acquirement and Demand Intensity of Family Support Service in the Background Variable of Special Student Family}

In order to find whether there are differences between acquirement and demand of family support service by special student families and gaps between the two, take the demand score minus the acquirements score to express the gap between demand and acquirements, so as to master whether current family support service meets the demands of special student families, here are the analysis and discussion on the gaps between acquirement and demand intensity under the variable of different family background.

1) Analysis of gaps between acquirement and demand of family support service by parents with different degrees: Seen from research results, fathers with different degrees in gaps between acquirement and demand in six dimensions have no obvious differences. Yet mothers with different degrees in gaps between two dimensions namely parental education course $(\mathrm{P}=.029<.05)$ and career planning $(\mathrm{P}=.029<.05)$ have obvious differences, the further analysis find that the higher the mother's degree is, the higher, their feeling in gaps between acquirement and demand of parental education course and children career planning service will be.

2) Analysis of gaps between acquirement and demand of family support service by parents with different jobs: Survey results show, fathers with different jobs have obvious differences only in gaps of the career planning dimension $(\mathrm{P}=.021<.05)$; mothers with different jobs have obvious differences in gaps between acquirement and demand of financial support, parental education course and career planning. The comparative analysis shows, the senses of gaps of fathers with medium-level occupation are higher than that of fathers with high-level occupation; the senses of gaps of mothers with low-level occupation are higher than that of mothers with medium-level occupation

TABLE IV. ANALYSIS OF GAPS BETWEEN ACQUIREMENT AND DEMAND OF FAMILY SUPPORT SERVICE BY MOTHERS WITH DIFFERENT JOBS

\begin{tabular}{|c|c|c|c|c|c|c|}
\hline & & $\begin{array}{c}\text { Quadratic } \\
\text { Sum }\end{array}$ & df & $\begin{array}{c}\text { Mean } \\
\text { square }\end{array}$ & $\mathbf{F}$ & $\begin{array}{c}\text { Obviousn } \\
\text { ess }\end{array}$ \\
\hline \multirow{3}{*}{$\begin{array}{l}\text { Gaps } \\
\text { financial } \\
\text { support }\end{array}$} & $\begin{array}{r}\text { Inter- } \\
\text { ofgroup }\end{array}$ & 5.438 & 2 & 2.719 & 3.554 & .031 \\
\hline & $\begin{array}{l}\text { Intra- } \\
\text { group }\end{array}$ & 144.581 & 189 & .765 & & \\
\hline & Total & 150.019 & 191 & & & \\
\hline \multirow{3}{*}{$\begin{array}{l}\text { Gaps } \\
\text { parental } \\
\text { education } \\
\text { course } \\
\text { support } \\
\end{array}$} & $\begin{array}{l}\text { ofInter- } \\
\text { group }\end{array}$ & 3.841 & 2 & 1.920 & 3.251 & .041 \\
\hline & $\begin{array}{l}\text { Intra- } \\
\text { group }\end{array}$ & 111.658 & 189 & .591 & & \\
\hline & Total & 115.499 & 191 & & & \\
\hline \multirow{3}{*}{$\begin{array}{l}\text { Gaps } \\
\text { career } \\
\text { planning } \\
\text { support }\end{array}$} & of $_{\text {group }}^{\text {Inter- }}$ & 6.971 & 2 & 3.486 & 4.999 & .008 \\
\hline & $\begin{array}{l}\text { Intra- } \\
\text { group }\end{array}$ & 131.774 & 189 & .697 & & \\
\hline & Total & 138.745 & 191 & & & \\
\hline
\end{tabular}

3) Analysis of gas between acquirement and demand of family service support by students with different handicaps: Research results show, due to the differences in students' handicaps, the parents have obvious differences in gaps between acquirement and demand intensity in six dimensions.
Comparative analysis shows, parents who have children with autism have obviously higher gaps in six dimensions than that those with other handicaps as, blind, deaf, dysgnosia and so on, seen a whole, the gaps in developmental disorder of parents are higher than that of sensor disorder.

TABLE V. ANALYSIS OF GAPS BETWEEN ACQUIREMENT AND DEMAND OF FAMILY SUPPORT SERVICE BY PARENTS OF STUDENTS WITH DIFFERENT HANDICAPS

\begin{tabular}{|c|c|c|c|c|c|c|}
\hline & & $\begin{array}{c}\text { Quadratic } \\
\text { Sum }\end{array}$ & df & \begin{tabular}{|c|} 
Mean \\
square
\end{tabular} & $\mathbf{F}$ & Obviousness \\
\hline Gaps of & Inter-group & 15.445 & 4 & 3.861 & 6.919 & .000 \\
\hline spiritual & Intra-group & 180.250 & 323 & .558 & & \\
\hline support & Total & 195.695 & 327 & & & \\
\hline Gaps of & Inter-group & 8.645 & 4 & 2.161 & 2.815 & .025 \\
\hline economic & Intra-group & 247.998 & 323 & .768 & & \\
\hline support & Total & 256.643 & 327 & & & \\
\hline Gaps of & Inter-group & 11.179 & 4 & 2.795 & 4.477 & .002 \\
\hline consultancy & Intra-group & 201.652 & 323 & .624 & & \\
\hline support & Total & 212.831 & 327 & & & \\
\hline Gaps of & Inter-group & 6.190 & 4 & 1.547 & 2.726 & .029 \\
\hline professional & Intra-group & 183.357 & 323 & .568 & & \\
\hline support & Total & 189.546 & 327 & & & \\
\hline Gaps of & Inter-group & 9.970 & 4 & 2.493 & 4.259 & .002 \\
\hline parental & Intra-group & 189.052 & 323 & .585 & & \\
\hline $\begin{array}{l}\text { education } \\
\text { course } \\
\text { support }\end{array}$ & Total & 199.022 & 327 & & & \\
\hline Gaps of & Inter-group & 15.676 & 4 & 3.919 & 5.284 & .000 \\
\hline career & Intra-group & 239.560 & 323 & .742 & & \\
\hline $\begin{array}{c}\text { planning } \\
\text { support }\end{array}$ & Total & 255.236 & 327 & & & \\
\hline
\end{tabular}

4) Analysis of gaps between acquirement and demand of family support service by students with different handicaps: Research results show, due to the differences in handicaps of students, parents have obvious differences in gaps between acquirement and demand of three dimensions as financial support, information support and professional support. The further analysis shows that the more serious the students' handicaps are the higher parents' senses of gaps between acquirement and demand.

TABLE VI. ANALYSIS OF GAPS BETWEEN ACQUIREMENT AND DEMAND OF FAMILY SUPPORT SERVICE By PARENTS OF STUDENTS WITH DIFFERENT HANDICAPS

\begin{tabular}{lllllll}
\hline & & $\begin{array}{c}\text { Quadratic } \\
\text { Sum }\end{array}$ & df & \multicolumn{1}{c}{$\begin{array}{c}\text { Mean } \\
\text { square }\end{array}$} & F & $\begin{array}{c}\text { Obviou } \\
\text { sness }\end{array}$ \\
\hline Gaps & ofInter-group & 15.047 & 3 & 5.016 & 6.726 & .000 \\
economic & Intra-group & 241.596 & 324 & .746 & & \\
support & Total & 256.643 & 327 & & & \\
\hline Gaps & ofInter-group & 9.822 & 3 & 3.274 & 5.225 & .002 \\
consultancy & Intra-group & 203.009 & 324 & .627 & & \\
support & Total & 212.831 & 327 & & & \\
Gaps & ofInter-group & 7.645 & 3 & 2.548 & 4.539 & .004 \\
professional & Intra-group & 181.901 & 324 & .561 & & \\
support & Total & 189.546 & 327 & & & \\
\hline $\begin{array}{l}\text { Gaps } \\
\text { career }\end{array}$ & ofInter-group & 10.367 & 3 & 3.456 & 4.573 & .004 \\
planning & Intra-group & 244.869 & 324 & .756 & & \\
support & Total & 255.236 & 327 & & & \\
\hline
\end{tabular}




\section{DISCUSSION}

A. Scores of Acquirements of Family Support Service in Six Dimensions by Special Student Family All Are Lower than that of the Demand, besides, the Differences Are Obvious

The acquirements of support service in six dimensions by special student families are not as good as expected, the demands are all extremely higher (average scores all exceed 3.4), besides, the there are obvious differences between acquirement and demand. On acquirements, the financial support gets the highest score, followed by consultancy support, still less than 3 points; the career planning gets the lowest score, 2.16 points only. On demands, the career planning gets the largest demand, followed by demand for information support, ye the demand for financial support is the lowest. The conclusion disagrees on the higher demands for financial support given earlier. Main reasons are state policies supports to special education, the disabled students and their families, especially the policies, costs and occupation supports to the disabled students at schooling age, all of these have greatly relived the pressure of special student families in finance. Just because of lowered economic pressure, going with the growth of special students, parents of whom have more worries for their survival in the future after grownup, so the demand for career planning is extremely urgent..

Seen from details, on the spiritual support, special student families are mostly encouraged and supported by teachers and leaders, but in the lack of tricks to relieve physical and mental pressure and methods for emotional control, which indicate that the families received more support in mentality among spiritual supports and little in technical support. On financial supports, the families receive more subsidies as tuition and textbook costs, little in costs of special equipment costs which are in an extremely high need. Though more investments are provided to students with disabilities, yet investments are uniform subsidies basically in special education schools where the handicaps are not classified, in fact, due to the handicap classification, intensity, special students have different demands for the support. On the information service, the families receive more information of direct service related to special student education, rehabilitation and the like and little of the rights protection and social resources that special students and their families should enjoy. On the professional service, seen from the differences between acquirement and demand, the families are in lack of technical support for rehabilitation and professional education needed by special students, mainly because, accompanying with the diversities of handicaps types and differences of special students, the demands of special students are diversified as well, i.e. language therapy, physical therapy and the forth.

\section{B. The Gaps between Acquirement and Demand Intensity of}

Family Support Service in All Dimensions by Special

Student Families Have Obvious Differences due to the

Differences in Parental Occupation, Degree and

Children's Handicaps Type and Intensity

Seen from variables of parents, mothers' senses of gaps in information support $(\mathrm{P}=.045<.05)$ and career planning $(\mathrm{P}=.018<.05)$ have obvious differences compared to that of fathers, and the first is obvious higher than the latter. On occupations, the gaps of mothers with low-level occupation in financial support, parental education course and career planning are all higher than mothers with senior and mediumlevel occupation, maybe because mothers are main caregivers to special children, who feel worried about the future of special children,[3] especially about on how to acquire information and career planning for the children. The gaps of mothers with bachelor's degrees in parental education course and career planning are obviously higher that of mothers with secondary specialized school degrees or middle school degrees, mainly because the higher the mothers' degrees are, the brisker and the more convenient their perception in information of family support will be, the more active they will be to master relevant policies, laws and welfare via various channels, therefore, compared to mothers with low-level degrees, they are easier to feel that the service acquired current is far to meet their demand[1].

Seen from students' handicaps, the gaps of parents of students with autism in six dimensions are obvious higher than that of other types as blind, deaf, dysgnosia and so on, in general, the gaps of parents of students with developmental disorder are higher than that of parents of students with sensory disorder, mainly because it analyzed relatively, students with developmental disorder have greater differences for some individuals, and their developing demands for social adaptation, self-care and so on are much diversified and more challenging, parents have to face higher pressure and worries in spirit, finance and career planning during looking after and breeding the children, yet current policies and services give little attentions to the handicaps classification, especially in lack of special service for autism; seen from the students' handicap intensity, the much serious is the handicaps in financial support, information support, professional support and career planning, the higher the gaps of parents will be, mainly because the much severe the handicaps are, the more difficult the students' education and rehabilitation will be, the higher the costs will be, the more and the much specialized the professional will be, besides, the effect of education and rehabilitation is not obvious, some even need a lifelong care, so the parents will have higher pressure [3].

\section{SUGGESTIONS}

\section{A. Educational Authorities}

1) Establish a perfect social security support system: Survey results show, the acquirements of support service in six dimensions by special student parents are obviously lower than the demand, so in order to lower the gaps between acquirement and demand the families in all dimensions, it is in an urgent need to establish a family advantage and family demandoriented support service system. The family support service shall not only make authorities accountable for relevant responsibilities but also need active participation of social fields so as to set up a multiple cooperative service network [9] characterized of primary community services, governmental instruction, family coordination, participation of social fields and present students and their families diverse, quality and convenient support services. 
2) Carry out policies related to the career planning of students: Researches find that parents with the disabled students have the highest demand for career planning, yet acquiring the least service. After graduation, special students are in the face of vocational training, employment placement and coming life arrangement. Schools pay more attentions to the preparation of vocational skills on the professional education for the disabled, but little to the students' career planning, employment information and coming employment tracking. Therefore, educational authorities shall carry out the existing policies, but also should keep close cooperation with communities, civil affairs departments and so on, establish policies to help the special student families to solve the students' career, employment and living placement in the future. [1]

3) Active to provide information concerning special education and welfare

Research results show, the acquirements of information support by special student families are a little higher than that of career planning, and its demand is a little lower than that of career planning, which prove that the families are in a serious lack of information acquirements in rights, social welfare security and rights protection related to the disabled, yet their demands are much higher. Therefore, education authorities should increase the transparency of information related to special education and welfare policies so that students' parents may know information about children's development, treatment, rehabilitation, education services, and rights protection and lower the chances of the parents in applying for and acquiring the welfare which may be missed due to lack of information. [1]

\section{B. Schools}

1) Strengthen students in career instruction: Researches show that career planning is a dimension with the highest demand by parents, especially further study of special students, employers to provide occupational exercise, coming job market guide and arrangement after leaving schools and more, all of which are support service in a great need for parents. Therefore, in addition to the self-care ability, social adaptability, professional attitudes and skills that should be strengthened in courses, the schools shall also discuss the students' coming career development with their parents [1], so that parents can plan the career development as early as possible for the students.

2) Intensify the publicity and inform the parents of information concerning special education and welfare: Researches find that the parents have higher demands for special education publicity, special education and welfare information. Therefore, schools are required to carry out regular special education publicity and provide important information concerning on special education and rehabilitation in time, in the meantime, the schools may offer the latest information or welfare measures by telephone, school websites, regular publications, etc., [7] to meet the demands of special student families for support services.

\section{CONClusion}

We have drawn four conclusions through the research, (1) the acquirements of support service by special student families are not as good as expected; (2) the demand intensity of support service by special student families are extremely high; (3) the acquirements of support service by special student families are lower than the demand intensity, with obvious differences found; (4) The gaps between acquirement and demand of family support service by special student families have obvious differences due to the differences in parental occupation, degree, children's handicaps classification and degree. In order to improve the quality of family support service for special student families, this article raises suggestions and opinions from educational agencies, schools and the society so as to provide references for those which provide family support services and enable the special student families to access to the support service.

\section{REFERENCES}

[1] Cheng Wanyu, Sun Shurou, Investigation of Demand and Support Service for Mentally Handicapped Student Families [J], Journal of Special Education, 2008.3: 55-75

[2] Huang Xinyin, Zhang Rui, Xing Yanqing, Investigation of Demand and Development Support for 71 Cases of Autism Families [J]. Chinese Journal of Special Education, 2009 (11): 43-47

[3] Gu Changfen, Chen Yaohong, Wang Rui, Investigation of Handicapped Children Aged 0-7 of Beijing [J]. Chinese Journal of Special Education, 2010 (10): 7-11

[4] Gu Changfen, Chen Yaohong, Cao Yan, Research on Demands of Parents with Handicapped Children Aged 0-6 of Beijing, [J]. Chinese Journal of Special Education, 2012 (4): 14-20

[5] Cai Zhuoni, Li Min, Zhou Chengyan, Survey and Analysis of Social Support to Special Children Families [J]. Chinese Journal of Special Education, 2010 (12): 17-20

[6] $\mathrm{Hu}$ Xiaoyi, Status Quo of Living Quality and Family Support to Handicapped Children Families of China [J]. Chinese Journal of Rehabilitation Theory and Practice, 2016.10:1227-1231

[7] Huang Jingjing, Liu Yanhong, Survey of Social Support to Special Children Families [J]. Chinese Journal of Special Education, 2006.4:3-9

[8] Xiong Yingqi, Gao Jie, Zhang Shasha, Research on Demands and Social Support to Autism Children Families [J]. China Collective Economy, 2015.10:165-166

[9] Feng Shanwei, Li Kun, Li Yun, Zhang Mengxin, Investigation of Status Quo and Demands for Basic Welfare of Handicapped Children [J]. 2016.3:33-39. 